\title{
TREND PEMILIHAN PENDIDIKAN ILMU PERPUSTAKAAN
}

\author{
Usiono \\ Universitas Islam Negeri Medan, Sumatera Utara, Indonesia \\ usiono@uinsu.ac.id \\ Retno Sayekti \\ Universitas Islam Negeri Medan, Sumatera Utara, Indonesia \\ retnosayekti69@gmail.com
}

\begin{abstract}
The School of Library and Information Science (LIS) is one of the growing field of studies in Indonesia. The growth of this school is in line with the recent development of information technology. Although this education has long been in existence in the history, the name and the positioning under certain faculty differs from one university to another. Although studies show that profession of librarian in Indonesia gains less interest from the society compared to other profession, the interest of student to study at LIS program at Universitas Islam Negeri (UIN) Sumatera Utara Medan has been increased since the beginning of its opening. This study aims at investigating factors that determine the students to choose Library and Information Science Department at UIN Sumatera Utara Medan. Using survey and Focused Group Discussion (FGD) techniques, this study found that there are four factors encouraging students to study at LIS program, they are self-motivation, parents' supports, other family members' supports, and friends' support. In terms of career, most students want to pursue their studies to a master degree to obtain a better profession in LIS program instead of working as information
\end{abstract}


specialists or librarians. Regarding the obstacles they face during the period of their study at LIS program, students maintain that lack of laboratory and lack of adequate resources have made their learning difficult. Therefore, they expect for the school to provide more trainings in hard and soft skills, especially in foreign languages and IT while updating the curricula to keep up to date with new trends in LIS.

Keywords: Library and Information Studies; Library Studies; Information Science; librarian; information specialist.

\begin{abstract}
Abstrak
Program Studi Ilmu Perpustakaan di Indonesia merupakan salah satu bidang pendidikan yang sedang berkembang sesuai dengan tuntutan perkembangan teknologi informasi dewasa ini. Sekalipun bidang pendidikan ini sudah cukup tua namun penamaan dan penempatan bidang pendidikan ini pada fakultas tidak sama antara satu Perguruan Tinggi dengan yang lainnya. Profesi pustakawan yang akan dihasilkan dari lulusan bidang pendidikan ilmu perpustakaan, masih merupakan profesi yang tak banyak diminati dibandingkan dengan profesi lainnya. Namun demikian, sejak dibukanya bidang pendidikan ini di UIN Sumatera Utara, minat calon mahasiswa untuk belajar di program studi Ilmu Perpustakaan meningkat dari tahun ke tahun. Karena itu, penelitian ini bertujuan untuk menggali data tentang faktor-faktor yang mendorong mahasiswa memilih program studi Ilmu Perpustakaan di Universitas Islam Negeri Sumatera Utara Medan. Dengan menggunakan tehnik pengumpulan data Focused Group Discussion (FGD), penelitian ini menemukan bahwa ada empat faktor yang mendorong mahasiswa memilih program studi Ilmu Perpustakaan, yaitu motivasi diri sendiri, orangtua, kerabat, dan teman sebaya. Dalam hal karir, sebagian besar mahasisw aingin melanjutkan studi untuk mendapatkan peluang kerja menjadi dosen pada Ilmu Perpustakaan. Hambatan-hambatan yang dihadapi oleh mahasiswa meliputi keterbatasan dalam sarana dan prasarana dan keterbatasan
\end{abstract}


kemampuan Bahasa asing. Karena itu, mahasiswa berharap agar program studi melakukan update kurikulum untuk menyesuaikan dengan perkembangan baru dalam Ilmu Perpustakaan dengan implementasi teknologi informasi dan menyelenggarakan program-program pelatihan dalam Bahasa asing dan IT.

Kata kunci: program studi ilmu perpustakaan; karir lulusan ilmu perpustakaan; pustakawan; ahli informasi.

\section{A. Pendahuluan}

Laju perkembangan Internet yang tinggi telah menjadi salah satu alasan utama munculnya fenomena ledakan informasi (information explosion). Namun permasalahan yang muncul adalah diantara informasi yang sedemikian banyak tentu menjadi lebih sulit dalam memilih informasi yang relevan dengan kebutuhan dan mengevaluasi informasi antara valid atau hoax, sebagaimana Casel \& Hiremath mengatakan bahwa informasi di era Internet ibarat gelombang ombak yang besar, namun diantara gelombang ombak yang besar itu kita harus mahir berselancar didalamnya. ${ }^{1}$ Kesadaran akan pentingnya informasi di era Internet saat ini disadari oleh lembaga pendidikan seperti perguruan tinggi. Lembaga perguruan tinggi merupakan salah satu tujuan masyarakat dalam meningkatkan pendidikan yang fokus dalam satu bidang konsentrasi yang dibutuhkan untuk memasuki dunia kerja. ${ }^{2}$ Era teknologi informasi juga telah merubah paradigm perpustakaan yang tida hanya sebagai penyedia wujud informasi tetapi juga menjadi penyedia akses informasi. Perubahan paradigm tersebut mewajibkan pustakawan sebagai pekerja informasi melek terhadap perkembangan teknologi, atau dapat diibaratkan dengan

${ }^{1}$ Kay Ann Cassel and Uma Hiremath, Reference and Information Service in the 21st Century: An Introduction (London: Facet Publishing, 2009).

${ }^{2}$ Sri Mulyatini and Tati Handayani, "Faktor-Faktor Yang Berpengaruh Terhadap Keputusan Memilih Program Studi” (Jakarta, 2010). 
"high tech \& high touch," yaitu perkembangan teknologi yang tinggi harus diimbangi dengan kompetensi yang tinggi. ${ }^{3}$

Pendidikan Ilmu Perpustakaan merupakan program studi yang sedang berkembang, dalam menyiapkan tenaga professional yang ahli di bidang informasi. Ilmu Perpustakaan muncul pada tahun 1923 di University of Chicago sebagai pionir pendidikan mengenai pustakawan, kemudian seiring dengan perkembangan zaman University of Philadelphia melahirkan Ilmu Informasi (Information Science) pada tahun 1959.4 Persepsi masyarakat terhadap program studi Ilmu Perpustakaan dinilai masih sangat rendah. Hal ini diperkuat oleh Purwanti dalam Khairunnisa yang dalam penelitiannya mengungkapkan bahwa profesi pustakawan dianggap sebelah mata oleh masyarakat dan masih sangat memprihatinkan di Indonesia. ${ }^{5}$ Pustakawan dianggap sebagai profesi kedua yang tidak penting. ${ }^{6}$ Pekerjaan yang dilakukan oleh pustakawan dianggap tidak menarik dan kurang memberikan tantangn. Oleh karenanya, profesi pustakawan tidak banyak diminati oleh masyarakat.

Kondisi ini berbanding terbalik dengan mahasiswa diluar negeri yang memilih belajar di Ilmu Perpustakaan sebagai pilihan sendiri sebagaimana yang diungkapkan oleh Janelys Cox. ${ }^{7}$

Beberapa penelitian terdahulu yang relevan telah dilakukan oleh para peneliti lain diantaranya adalah sebagaimana diuraikan dibawah ini.

\footnotetext{
${ }^{3}$ Cassel and Hiremath, Reference and Information Service in the 21st Century: An Introduction.

${ }^{4}$ Sulistyo Basuki, Periodisasi Perpustakaan Indonesia (Bandung: PT. Remaja Rosdakarya, 1994).

${ }^{5}$ Khairunnissa, "Faktor-Faktor Yang Mendorong Pemilihan Program Studi Ilmu Perpustakaan Oleh Mahasiswa Llmu Perpustakaan Universitas Sumatera Utara" (Medan, 2015), doi:10.1007/s13398-014-0173-7.2.

${ }^{6}$ Dian Hapsari, "Menjadi Pustakawan Profesional Bersama Ikatan Pustakawan Indonesia (IPI)," EduLib 1, no. 1 (2011): 119-26.

${ }^{7}$ Jennifer Everson Brown, Jenelys Cox, and Emily Tormey, "Working Toward the MLIS: Library Students in Access Services," Journal of Access Services 10, no. 1 (2013): 61-67, doi:10.1080/15367967.2013.738394.
} 
Penelitian yang telah dilakukan mengenai motivasi mahasiswa memilih jurusan Ilmu Perpustakaan di USU yang dilakukan oleh Siahaan mengungkapkan bahwa faktor yang mendorong mahasiswa memilih jurusan Ilmu Perpustakaan USU adalah prosentase terbesar karena dorongan orangtua atau saudara. Motivasi mahasiswa memilih program studi tersebut dikarena peluang kerja yang luas dan peluang untuk masuk ke USU lebih besar karena passing grade program studi Ilmu Perpustakaan terbilang rendah sehingga persaingan tidak terlalu ketat. ${ }^{8}$

Mulyatini dan handayani dalam penelitian mereka yang berjudul "Faktor-faktor yang berpengaruh terhadap keputusan memilih program studi" menyimpulkan bahwa faktor-faktor yang berpengaruh terhadap keputusan memilih program studi terdiri dari 18 variabel yang terbentuk menjadi 5 faktor yang berbeda. ${ }^{9}$ Penelitian yang menggunakan pendekatan kuantitatif ini menguraikan bahwa kelima faktor tersebut adalah kesatu, terdiri dari variable fasilitas program studi, lingkungan program studi, gedung dan perpustakaan. Kemudian faktor satu ini dinamakan faktor fisik. Faktor kedua terdiri dari variable ketersediaan beasiswa, dosen, teman, keberhasilan alumni, memperoleh pekerjaan, dan isu positif. Kemudian faktor dua ini diberi namafaktor jaminan kerja. Faktor ketiga terdiri dari variabel biaya pendidikan, persyaratan pembayaran, keluarga dan penghasilan orangtua. Kemudian faktor tiga ini dinamakan faktor biaya kuliah. Faktor keempat terdiri dari variable kurikulum dan silabus, serta citra. Kemudian faktor empat ini dinamakan faktor persepsi. Faktor kelima terdiri dari variable status akreditasi dan potongan biaya pendidikan. Faktor kelima ini dinamakan faktor promosi.

Didalam penelitian yang dilakukan oleh Setiawan dengan judul "Persepsi Mahasiswa Baru dan Akhir Program Studi Ilmu

${ }^{8}$ Hotlan Siahaan, Faktor-Faktor Yang Melatarbelakangi Mahasiswa Memilih Program Studi Ilmu Perpustakaan Universitas Sumatera Utara (Medan: Fakultas Ilmu Budaya. Universitas Sumatera Utara: Medan., 2010).

${ }^{9}$ Mulyatini and Handayani, "Faktor-Faktor Yang Berpengaruh Terhadap Keputusan Memilih Program Studi." 
Informasi dan Perpustakaan terhadap Lapangan Kerja di Bidang Program Studi Ilmu Informasi dan Perpustakaan (Studi Deskriptif pada mahasiswa IIP Unair sebagai Penunjang Kegiatan Akademis) menyimpulkan bahawa alasan mahasiswa memilih program studi Ilmu Perpustakaan adalah sebagai pilihan kedua, yaitu pilihan cadangan apabila tidak lulus pada pilihan pertama mereka. Disamping itu pemilihan program studi Ilmu Perpustakaan juga merupakan dorongan dari orangtua. ${ }^{10}$ Penelitian yang bertujuan membedakan persepsi antara mahasiswa baru dan mahasiswa lama tentang karir pustakawan ini menegaskan bahwa peran orangtua merupakan dorongan terbesar bagi mayoritas mahasiswa program studi Ilmu Perpustakaan.

Penelitian ini berusaha menggali informasi tentang faktorfaktor yang mendorong mahasiswa memilih program studi Ilmu Perpustakaan di Universitas Islam Negeri Sumatera Utara Medan.

\section{B. Pembahasan}

Penelitian ini menggunakan pendekatan kualitatif deskriptif untuk menggali informasi tentang pengalaman dan pendapat dari responden. Adapun data-data yang dikumpulkan melalui metode ini adalah pengalaman responden dalam menentukan pilihan kepada program studi Ilmu Perpustakaan UIN Sumatera Utara Medan; pendapat serta harapan responden mengenai karir di masa depan serta harapan mereka terhadap program studi. Tehnik pengumpulan data dalam penelitian ini dilakukan dengan tehnik survey dan Focused Group Discussion (FGD). Adapun tehnik penentuan sampel adalah dengan metode purposive sampling.

Dari hasil analisa data ditemukan bahwa terdapat 4 faktor pendorong mahasiswa memilih program studi Ilmu Perpustakaan UIN Sumatera Utara Medan, antara lain:

${ }^{10}$ Lukas Dwiky Setiawan, "Persepsi Mahasiswa Baru Dan Akhir Program Studi Ilmu Informasi Dan Perpustakaan Terhadap Lapangan Kerja Di Bidang Program Studi Ilmu Informasi Dan Perpustakaan (Studi Deskirptif Pada Mahasiswa IIP Unair Sebagai Penunjang Kegiatan Akademis)," 1986. 
Atas dasar keinginan diri sendiri. Sebanyak 67 responden $(36,2 \%)$ atau dnegan kata lain mayoritas mahasiswa memilih prodi Ilmu Perpustakaan berasal dari keinginan diri sendiri. Motivasi muncul dari pribadi individu berdasarkan atas persepsi yang terbentuk dari informasi tentang ilmu perpustakaan yang telah dimiliki dan diyakini dari berbagai sumber. Salah satu informasi yang diyakini adalah bahwa ilmu perpustakaan merupakan prodi yang yang terbilang langka sehingga persepsi yang terbentuk adalah prospek ruang kerja yang masih luas dan dibutuhkan. Selain itu, motivasi yang terbentuk atas dasar keinginan sendiri muncul disebabkan oleh pengalaman mahasiswa yang sudah pernah berkecimpung dalam dunia perpustakaan serta informasi dari orang terdekat yang sudah bekerja di perpustakaan. Keberadaan prodi ilmu perpustakaan di UIN Sumatera Utara menjadi daya tarik tersendiri bagi mahasiswa. Daya Tarik itu muncul karena UIN Sumatera Utara merupakan perguruan tinggi keislaman negeri yang masih baru membuka prodi Ilmu Perpustakaan sehingga peluang untuk lulus terbilang besar serta UIN Sumatera Utara menawarkan materi-materi spesifik keagamaan didalam kurikulum pembelajaran yang bisa didapatkan untuk memperkaya ilmu agama.

Faktor orangtua. Hasil data survey menunjukkan bahwa faktor orangtua termasuk kedalam salah satu faktor pendorong terbesar mahasiswa memilih program studi Ilmu Perpustakaan UIN Sumatera Utara Medan. Mayoritas orangtua yang mendorong mahasiswa memilih prodi Ilmu Perpustakaan UIN Sumatera Utara berlatar belakang seorang pendidik. Banyak pertimbangan yang membuat orangtua memutuskan untuk mendorong anaknya masuk ke prodi Ilmu Perpustakaan UIN Sumatera Utara Medan. Bagi seorang pendidik pertimbangan itu muncul dari pengalamannya melihat kondisi perpustakaan di sekolah tempat ia mengajar yang dirasa memprihatinkan dan informasi yang didapatkan dari pengelola perpustakaan sekolah. Informasi itu mengarah pada ketidakmampuan individu (pengelola perpustakaan) dalam 
mengelola perpustakaan sekolah serta masih minimnya orangorang yang bergelar sarjana Perpustakaan, namun disisi lain kebutuhan akan pengelola perpustakaan (pustakawan) masih sangat dibutuhkan dan berpeluang besar untuk dapat diterima di dunia kerja. Selain itu, materi-materi keagamaan yang spesifik dalam kurikulum pembelajaran yang ditawarkan oleh UIN Sumatera Utara Medan menjadi daya tarik terbesar orangtua untuk memasukkan anaknya ke prodi Ilmu Perpustakaan UIN Sumatera Utara. Pertimbangan lainnya dari orangtua adalah terfokus pada persepsi yang terbentuk bahwa kuliah merupakan salah satu cara terbaik untuk mencapai kesuksesan. Orangtua tidak terfokus pada pilihan program studi yang akan dijalani, namun lebih kepada kuliah di perguruan tinggi negeri dengan anggapan biaya yang relative lebih murah diandingkan perguruan tinggi swasta.

Faktor kerabat/keluarga. Bentuk dukungan dari pihak kerabat/keluarga yang mendorong mahasiswa memilih prodi Ilmu Perpustakaan UIN Sumatera Utara Medan berdasarkan pengalaman dan relasi. Pengakuan dari informan bahwa salah satu kerabat yang bekerja di instansi BKN memberikan informasi peluang ilmu perpustakaan terbuka lebar di masa yang akan datang. Secara kuantitas sarjana ilmu perpustakaan masih minim khususnya di propinsi Sumatera Utara, dan kedepannya sarjana ilmu perpustakaan sangat dibutuhkan oleh setiap instansi. Hal itu yang kemudian mendorong mahasiswa maupun pihak orangtua memiliki keinginan untuk masuk ke prodi Ilmu Perpustakaan UIN Sumatera Utara. Selain itu, faktor kerabat/keluarga berupa pengalaman langsung di instansi perpustakaan. Kerabat yang sudah bekerja di instansi perpustakaan memberi masukan kepada mahasiswa terkait dengan peluang dan tantangan sarjana ilmu perpustakaan di masa yang akan datang. Disamping memberikan masukan, pihak kerabat sebelumnya juga sering mengajak mahasiswa tersebut untuk membantunya bekerja di perpustakaan selama beberapa minggu. Pengakuan mahasiswa bahwa ia merasa asyik dan tertarik untuk berkecimpung di dunia perpustakaan setelah 
mengetahui seluk beluk perpustakaan dan melihat penghasilan sebagai PNS ilmu perpustakaan cukup menghidupi diri sendiri dan keluarga. Hal itu yang menjadi pendorong mahasiswa kemudian ingin memilih prodi Ilmu Perpustakaan. Pemilihan UIN Sumatera Utara sebagai institusi yang membuka prodi Ilmu Perpustakaan untuk melanjutkan pendidikannya disebabkan oleh peluang untuk diterima masih terbuka lebar mengingat prodi Ilmu Perpustakaan UIN Sumatera Utara pada saat itu masih penerimaan mahasiswa angkatan pertama. Selain itu, dorongan dari pihak kerabat juga ada yang menjurus kepada tawaran untuk mengelola perpustakaan sekolah tempat ia bekerja setelah menyelesaikan studi.

Faktor teman/sahabat. Salah satu aspek pendorong mahasiswa memilih prodi Ilmu Perpustakaan UIN Sumatera Utara Medan adalah berasal dari masukan atau dukungan teman. Menurut hasil survey, faktor teman/sahabat terlalu signifikan sebagai mesin pendorong mahasiswa memilih jurusan ilmu perpustakaan. Dari data FGD yang diterima bahwa mayoritas teman/sahabat juga tidak begitu mengetahui tentang keberadaan prodi Ilmu Perpustakaan, bahkan sebahagiannya menertawakan sembari meremehkan akan peluang kerja ketika sudah menjadi sarjana. Persepsi akan citra perpustakaan yang berasal dari teman/sahabat bahwa perpustakaan hanya bekerja menyususn dan menjaga buku. Bentuk dukungan dari teman/sahabat bagi mahasiswa dalam memilih prodi ilmu perpustakaan memiliki passing grade yang rendahsehingga peluang untuk lulus terbuka lebar. Bentuk dukungan bukan karena menganggap prodi Ilmu Perpustakaan itu bagus tetapi lebih kepada dukungan agar dapat lulusa kedalam Perguruan Tinggi Negeri.

Adapun alasan mengapa mahasiswa memilih program studi Ilmu Perpustakaan adalah sebagai berikut: 
Tabel 1: Prosentase Mahasiswa Memilih Prodi Ilmu Perpustakaan

\begin{tabular}{lc}
\hline \multicolumn{1}{c}{ Alasan utama memilih program studi Ilmu } & Prosentese (\%) \\
\hline Peluang kerja yang luas & 74,6 \\
Kebetulan saja & 13,6 \\
Agar bisa kuliah di Pergutuan Tinggi Negeri & 9,2 \\
Untuk mencapai cita-cita & 2,7 \\
\hline
\end{tabular}

Berdasarkan hasil survey diatasdapat diinterpretasikan bahwa sebanyak 137 responden (74,5\%) mengatakan alasan utama memilih program studi Ilmu Perpustakaan disebabkan peluang kerja yang bagus. Dari data FGD ditemukan bahwa mayoritas mahasiswa yang menjawab alasan tersebut adalah berangkat dari persepsi awal mengenai prodi Ilmu Perpustakaan yang dimana peluang kerja bagi lulusan masih terbuka lebar akibat sarjana/ lulusan prodi Ilmu Perpustakaan masih terbilang minim.alasan tersebut tercipta sebagian besar berasal dari informasi dan pengalaman dari keluarga maupun kerabat yang sudah pernah bekerja di dunia perpustakaan.

Sebanyak 25 responden (13,5\%) mengaku memilih prodi Ilmu Perpustakaan hanya suatu kebetulan saja. Dari data FGD ditemukan bahwa alasan "kebetulan saja" berangkat dari kebingungan mahasiswa dalam memilih prodi yang peluang untuk lulusnya tingi dan bukan pada pilihan pertama. Mayoritas mahasiswa yang menjawab dnegan alasan ini adalah mahasiswa yang menjadikan ilmu perpustakaan di pilihan ke tiga dana tau terakhir pada ujian masuk PTN. Alasan dipilihnya ilmu perpustakaan pada pilihan ke tiga atau terakhir adalah berdasarkan passing grade yang paling rendah atau peluang untuk lulus terbilang besar.

Sebayak 17 responden (9,2\%) mengatakan alasan utama memilih prodi Ilmu Perpustakaan hanya sekedar agar dapat menimba ilmu di perguruan tinggi negeri. Beberapa mahasiswa memilih prodi ilmu perpustakaan UIN Sumatera Utara Medan hanya agar dapat melanjutkan studi di Perguruan Tinggi Negeri. Alasan yang muncul adalah dorongan dari pihak keluarga agar 
tidak terlalu besar membayar biaya kuliah. Artinya, tidak begitu penting prodi yang dipilihnya asalkan perguruan tinggi negeri. Untuk menemukan jalan masuk agar lulus ke perguruan tinggi negeri, prodi yang dipilih haruslah yang passing gradenya rendah ataupun peminatnya sedikit. Selain itu alasan yang muncul adalah menghindari cemoohan dari teman/sahabat sekiranya tidak lulus kedalam perguruan tinggi negeri. Sifat gengsi ini mereduksi pentingnya memilih prodi yang tepat dalam suatu perguruan tinggi. Beberapa teman/sahabat masih menganggap bahwa apabila kuliah di perguruan tinggi swasta termasuk orang yang kurang cerdas. Persepsi ini terbentuk sudah cukup lama. Beberapa orangtua juga berpendapat demikian, selain menghindari biaya yang besar, perguruan tinggi negeri dianggap memproduksi lulusan-lulusan terbaik dan cepat mendapatkan pekerjaan. Yang cukup menarik adalah adanya 5 orang responden $(2,7 \%)$ yang mengatakan untuk mencapai cita-cita sebagai alasan utama memilih prodi Ilmu Perpustakaan. Ilmu Perpustakaan dijadikan sebagi bekal kemampuan mengarungi bursa pekerjaan. Alasan itu muncul karena ia sudah mengetahui seluk beluk dunia perpustakaan, peluang tantangan ilmu perpustakaan secara spesifik dimasa yang akan datang sehingga itu yang melahirkan keinginannya memilih ilmu perpustakaan sebagai bekal untuk mencapai cita-cita. Bukan hanya profesi sebagai pustakawan yang ingin dikerjarnya, tetapi profesi lain yang berkaitan dnegan pekerja informasi seperti konsultan informasi, controller document, information broker, dan lain sebagainya.

Dari kegiatan FGD yang dilakukan ditemukan bahwa mayoritas mahasiswa merasa senang dan lebih percaya diri akan jurusan Ilmu Prpustakaan yang telah dipilihnya sehingga ingin belajar lebih jauh mengenai ilmu perpustakaan. Pola pikir memilih prodi ilmu perpustakaan hanya sebatas coba-coba atau terpaksa, namun setelah menggeluti dan mempelajari di bangku perkuliahan membuat mindset mereka perlhan mulai berubah. Materi-materi yang sudah dipelajari ternyata tidak sesulit yang dibayangkan dan 
oerlahan membuat mereka merasa lebih yakin akan masa depan lulusan prodi ilmu perpustakaan sangatlah dibutuhkan. Kemampuan yang dimiliki oleh lulusan ilmu perpustakaan sangat dibutuhkan di era informasi seperti saat ini dan akan datang. Pemanfaatan teknologi informasi yang menjamur di segala bidang pekerjaan akan sangat membutuhkan para pelaku dan penyedia informasi seperti lulusan ilmu perpustakaan untuk memenuhi kebutuhan informasi. Disamping itu, mindset mahasiswa mulai terbuka terkait dnegan pekerjaan yang digelutinya dengan tidak terbatas hanya sebagai pustakawan saja, namun dapat diexplor lebih jauh lagi seperti konsultan informasi, pengelola informasi, document controller dan sebagainya. Persepsi awalnya yang terbentuk bahwa belajar di ilmu perpustakaan hanya sekedar diajarkan bagaimana menyusun buku seakan sirna setelah menjalani materi-materi yang diajarkan di prodi ilmu perpustakaan. Kurikulum pembelajaran yang telah dijalani membuat mahasiswa yakin akan kompetensi yang mereka miliki dapat diterima di dunia kerja yang sarat akan persaingan.

Berdasarkan hasil survey mengenai persepsi mahasiswa tentang prodi ilmu perpustakaan tercatat sebanyak 142 responden (76,8\%) meyakini bahwa ilmu perpustakaan adalah ilmu yang memiliki peluang kerja yang bagus. Dari data FGD ditemukan bahwa mayoritas mahasiswa awalnya tidak pernah mengetahui apa itu perpustakaan, bagaimana kuliah di jurusan ilmu perpustakaan dan pekerjaan seperti apa setelah lulus nanti. Persepsi bahwa ilmu perpustakaan memiliki peluang kerja yang bagus kedepannyabukan berasal dari internal diri sendiri, tetapi eksternal. Faktor orangtua, keluarga, kerabat menjadi sumber informasi yang membentuk persepsi mahasiswa bahwa ilmu perpustakaan memiliki peluang kerja yang bagus. Pengalaman dari orang terdekat yang sudah pernah terjun langsung kedalam dunia perpustakaan yang kemudian mengatakan bahwa "belajar ilmu perpustakaan itu enak, lulusan ilmu perpustakaan masih minim, sarjana ilmu perpustakaan masih sedikit sehingga peluang kerja terbuka lebar," pernyataan itu 
yang membentuk persepsi mahasiswa yang meyakini bahwa ilmu perpustakaan memiliki peluang kerja yang bagus.

Mengenai karir masa depan, mayoritas mahasiswa berkeinginan untuk mengembangkan ilmu perpustakaan dengan melanjutkan studi pada program magister. Hal ini berdasarkan atas ketertarikannya belajar di prodi ilmu perpustakaan yang telah dijalani dalam beberapa semester ini serta pengalaman dan inspirasi dari beberapa dosen yang mengajar di prodi ilmu perpustakaan UIN Sumatera Utara. Selain itu, alasan ingin melanjutkan ke jenjang magister adalah terkait dengan keinginannya menjadi seorang pengajar atau dosen. Dosen dianggap sebagai pekerjaan yang terhormat dan mulia dnegan pengahsilan diatas ratarata. Disamping itu juga ada dukungan dari orangtua yang menginginkan anaknya untuk melanjutkan studi magister bagi orangtua yang mampu.

Berdasarkan dari hasil temuan diatas, faktor dorongan dari diri sendiri mahasiswa dalam memilih program studi Ilmu Perpustakaan cukup banyak. Ini merupakan suatu fakta positif dimana mahasiswa telah terlebih dahulu menelusuri pengetahuan bahkan pengalaman dalam bidang ilmu perpustakaan untuk meyakinkan diri menentukn pilihan program studi Ilmu Perpustakaan. Faktor dorongan dari diri sendiri ini, sekalipun mahasiswa pada umumnya masih belum mengetahui apa yang akan mereka pelajari pada program studi Ilmu Perpustakaan, akan menjadi lebih kuat apabila pada saat menjalani program pendidikan mereka juga diberi pengalaman terlibat dalam tugastugas di Perpustakaan. Kombinasi antara dorongan diri sendiri, teori yang dipelajariserta praktek di lapangan akan membuka peluang peningkatan kualitas studi dan kerja. ${ }^{11}$

Sebelum memasuki dan memilih program studi Ilmu Perpustakaan, mahasiswa telah memiliki pengetahuan, persepsi, harapan dan konsep diri terhadap ilmu pengetahuan dan profesi

\footnotetext{
${ }^{11}$ Brown, Cox, and Tormey, "Working Toward the MLIS: Library Students in Access Services.”
} 
pustakawan. Keterbatasan akses tentang ilmu perpustakaan membuat mahasiswa tidak percaya diri memilih bekerja di perpustakaan dan profesi pustakawan sebagai karirnya di masa yang akan datang. Bahkan bagi sebagian mahasiswa program studi ini dijadikan sebagai alternatif terakhir atau "ketimbang tidak kuliah.” Sedikit sekali mahasiswa yang menjadikan program studi Ilmu Perpustakaan sebagai alternatif pertama. Berdasarkan informasi yang mereka dapat dari berbagai sumber, bahwa program studi Ilmu Perpustakaan memiliki lapangan pekerjaan yang tidak jelas, bahkan sebagian mahasiswa mengaku tidak tahu apa yang akan ia pelajari pada program studi ini.

Konsep diri yang dibawa mayoritas mahasiswa ketika memasuki program studi Ilmu Perpustakaan ini memberikan pengaruh terhadap level belajar mereka. Inilah yang disebut dengan entry behavior. Berdasarkan penelitian 95\% riset menemukan bahwa entry behavior peserta didik menjadi variabel kunci yang memiliki dampak positif dan membantu dalam proses belajar. ${ }^{12}$ Entry behavior adalah semua karakteristik individu siswa sebelum memasuki tingkat pendidikan tertentu. Entry behavior ini meliputi aspek pengetahuan, persepsi, dan juga harapan terhadap pelajaran. Affective entry behaviorsmerupakan kombinasi dari minat mahasiswa, sikap dan konsep diri terhadap matakuliah atau unit pelajaran tertentu. akan tetapi, penelitian membuktikan bahwa konsep diri yang rendah terhadap pelajaran tidak secara otomatis berhubungan dengan rendahnya capaian pembelajaran dalam perkuliahan.

Mayoritas mahasiswa berpendapat bahwa peluang kerja bagi lulusan masih terbuka lebar akibat sarjana/lulusan prodi ilmu perpustakaan masih terbilang minim. Ini menunjukkan bahwa peluang kerja sebagai tujuan akhir yang ingin diraih oleh mahasiswa pada saat setelah menyelesaikan program studinya.

${ }^{12}$ Muhittin Çaliskan, "Effect of Cognitive Entry Behaviors and Affective Entry Characteristics on Learning Level," Educational Sciences: Theory \& Practice 14, no. 5 (2014): 1816-21, doi:DOI: 10.12738/estp.2014.5.1834. 
Sebagaimana yang diungkapkan oleh teori, bahwa faktor tujuan juga dapat menjadi pendorong bagi mahasiswa menetapkan program studi. ${ }^{13}$ Menurut teori yang dikemukakan oleh Locke ini bahwa tujuan mendorong seseorang untuk berperilaku dan bertindak tertentu untuk mencapai tujuannya. Tujuan memotivasi orang untuk mengembangkan strategi yang akan membuat mereka mampu bertindak sesuai dengan ketercapaian tingkat tujuan. Seorang mahasiswa dnegan orientasi tujuan belajar tertentu akan mengembangkan kompetensinya dengan menguasai situasi tantangan. Penelitian menunjukkan bahwa orientasi tujuan belajar memiliki dampak positif terhadap perilaku yang terkait dengan kerja dan unjuk kerja seseorang.

Dorongan dari orangtua dan lingkungan termasuk kerabat, teman dan sekolah memainkan peran yang penting bagi mahasiswa dalam memutuskan program studi yang akan diambil. Beberapa penelitian membuktikan besarnya pengaruh orangtua dalam pengambilan keputusan tersebut. ${ }^{14}$ Motivasi keberhasilan yang tinggi dari seorang anak merupakan hasil dari dorongan orangtua dengan penguatan-penguatan yang positif. ${ }^{15}$

Dorongan belajar yang datang secara internal dari dalam diri sendiri pada umumnya merupakan faktor yang paling baik bagi mahasiswa untuk belajar di Program Studi Ilmu Perpustakaan. Ini terbukti pada mahasiswa yang memiliki pilihan sendiri untuk masuk prodi Ilmu Perpustakaan cenderung lebih bersemangat dalam

${ }^{13}$ Fred C Lunenburg, "Goal-Setting Theory of Motivation," International Journal of Management, Business, and Administration 15, no. 1 (2011), http:// www.nationalforum.com/Electronic Journal Volumes/Lunenburg, Fred C. GoalSetting Theoryof Motivation IJMBA V15 N1 2011.pdf.

${ }^{14}$ Basilia Ria Irmawati, "Faktor-Faktor Yang Mempengaruhi Mahasiswa Dalam Memilih Program Studi Di Perguruan Tinggi" (Universitas Sanata Dharma Yogyakarta, 2008); Nalim, "Analisis Faktor Yang Mempengaruhi Mahasiswa Dalam Memilih Program Studi Bahasa Arab STAIN Pekalongan," Forum Tarbiyah2 10, no. 2 (2012): 214-35; Wan Suryani and Paham Ginting, "Faktor-Faktor Yang Mempengaruhi Keputusan Mahasiswa Memilih Fakultas Ekonomi Universitas Islam Sumatera Utara Al-Munawaroh Medan," Modernisasi 9, no. 3 (2013): 33-48.

${ }^{15}$ Michael Bolduc, Power of Motivation (Vancouver: Guaranteed Success Strategies, 2000). 
belajar, mampu mengembangkan ide-ide yang lebih kreatif dan inovatif dalam melaksanakan kegiatan-kegiatan yang meningkatkan keterampilan mereka dalam pengelolaan perpustakaan.

Sementara bagi mahasiswa yang memilih program studi Ilmu Perpustakaan karena dorongan orangtua atau keluarga dekat, sekalipun motivasinya datang secara eksternal, namun kelompok mahasiswa ini mendapatkan dukungan-dukungan yang cukup kuat dari orang tua dan kerabat mereka sehingga mereka juga memiliki rasa percaya diri dan keyakinan terhadap peluang kerja dan masa depan yang baik.

\section{Simpulan}

Ada 4 faktor mahasiswa memilih program studi Ilmu Perpustakaan UIN Sumatera Utara Meda; keinginan sendiri, dorongan orangtua, dorongan kerabat, dorongan teman, hal ini membuktikan dukungan yang kuat juga dari lingkungan keluarga, kemudian peluang pasar kerja yang terbuka lebar menjadi alasan rasional bagi yang menentukan pilihannya di prodi Ilmu Perpustakaan.

Karir yang diharapkan setelah selesai kuliah di prodi Ilmu Perpustakaan adalah memiliki peluang kerja yang bagus yang didasarkan pada kebutuhan akan lulusan Ilmu Perpustakaan yang masih sangat terbatas sementara kebutuhan sangat banyak dan terbuka lebar, hal ini menjadi perhatian serius bagi penyedia sumber daya manusia (SDM) di bidang ilmu perpustakaan dengan segala upaya harus dapat memastikan ketersediaan sesuai dengan kebutuhan. Hal ini didukung dari tujuan memilih prodi Ilmu Perpustakaan untuk mengembangkan diri di lingkungan masyarakat secara orisinil. Hal ini memperkokoh lulusan menjadi bagian dari solusi. 


\section{DAFTAR PUSTAKA}

Basuki, Sulistyo. Periodisasi Perpustakaan Indonesia. Bandung: PT. Remaja Rosdakarya, 1994.

Bolduc, Michael. Power of Motivation. Vancouver: Guaranteed Success Strategies, 2000.

Brown, Jennifer Everson, Jenelys Cox, and Emily Tormey. "Working Toward the MLIS: Library Students in Access Services." Journal of Access Services 10, no. 1 (2013): 61-67. doi:10.108 0/15367967.2013.738394.

Çaliskan, Muhittin. "Effect of Cognitive Entry Behaviors and Affective Entry Characteristics on Learning Level." Educational Sciences: Theory \& Practice 14, no. 5 (2014): 1816-21. doi:DOI: 10.12738/estp.2014.5.1834.

Cassel, Kay Ann, and Uma Hiremath. Reference and Information Service in the 21st Century: An Introduction. London: Facet Publishing, 2009.

Hapsari, Dian. "Menjadi Pustakawan Profesional Bersama Ikatan Pustakawan Indonesia (IPI).” EduLib 1, no. 1 (2011): $119-26$.

Irmawati, Basilia Ria. "Faktor-Faktor Yang Mempengaruhi Mahasiswa Dalam Memilih Program Studi Di Perguruan Tinggi." Universitas Sanata Dharma Yogyakarta, 2008.

Khairunnissa. "Faktor-Faktor Yang Mendorong Pemilihan Program Studi Ilmu Perpustakaan Oleh Mahasiswa Llmu Perpustakaan Universitas Sumatera Utara.” Medan, 2015. doi:10.1007/s13398-014-0173-7.2.

Lunenburg, Fred C. "Goal-Setting Theory of Motivation." International Journal of Management, Business, and Administration 15, no. 1 (2011). http://www.nationalforum. com/Electronic Journal Volumes/Lunenburg, Fred C. GoalSetting Theoryof Motivation IJMBA V15 N1 2011.pdf. 
Mulyatini, Sri, and Tati Handayani. "Faktor-Faktor Yang Berpengaruh Terhadap Keputusan Memilih Program Studi." Jakarta, 2010.

Nalim. "Analisis Faktor Yang Mempengaruhi Mahasiswa Dalam Memilih Program Studi Bahasa Arab STAIN Pekalongan." Forum Tarbiyah2 10, no. 2 (2012): 214-35.

Setiawan, Lukas Dwiky. "Persepsi Mahasiswa Baru Dan Akhir Program Studi Ilmu Informasi Dan Perpustakaan Terhadap Lapangan Kerja Di Bidang Program Studi Ilmu Informasi Dan Perpustakaan (Studi Deskirptif Pada Mahasiswa IIP Unair Sebagai Penunjang Kegiatan Akademis)," 1986.

Siahaan, Hotlan. Faktor-Faktor Yang Melatarbelakangi Mahasiswa Memilih Program Studi Ilmu Perpustakaan Universitas Sumatera Utara. Medan: Fakultas Ilmu Budaya. Universitas Sumatera Utara: Medan., 2010.

Suryani, Wan, and Paham Ginting. "Faktor-Faktor Yang Mempengaruhi Keputusan Mahasiswa Memilih Fakultas Ekonomi Universitas Islam Sumatera Utara Al-Munawaroh Medan." Modernisasi 9, no. 3 (2013): 33-48. 